\title{
A review of secondary school EFL teacher professional development in China
}

Urgamal, Lkhagvasuren

National University of Mongolia, Mongolia (U_lhagvaa2000@yahoo.com)

Taye, Markos

University of Gondar, Ethiopia (markostezera_abe@yahoo.com)

Muthanna, Abdulghani

OsloMet - Oslo Metropolitan University, Norway (abdulghani.muthanna@oslomet.no)

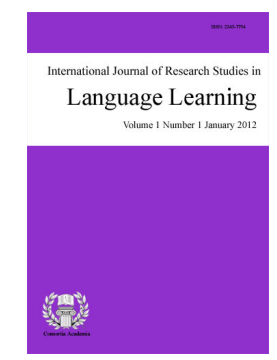

ISSN: 2243-7754 Online ISSN: 2243-7762

OPEN ACCESS

Sang, Guoyuan

Beijing Normal University, China (guoyuan.sang@bnu.edu.cn)

\section{Abstract}

Teacher professional development enhances the theoretical knowledge and practical experience of teachers. By reviewing previous studies related to secondary EFL teacher professional development in China, this review paper reports on the development and importance of English, the value of secondary EFL teacher professional development, and the actual practices of EFL teacher professional development in the context of China. It also highlights the need for stronger practices in the professional development of teachers, and the financial supports in particular.

Keywords: China; English; teacher professional development; EFL; teachers 


\section{A review of secondary school EFL teacher professional development in China}

\section{Introduction}

The teaching profession demands well-prepared and qualified teachers who would perform it professionally and assist in students' mental and knowledge growth. Currently, there is a stronger emphasis on the concept of teacher professional development (TPD) which can be defined as a means for developing teachers' learning and teaching performances that also change beliefs and perceptions of teachers (e.g. Day \& Sachs, 2004; Goldschmidt \& Phelps, 2010; Tao \& Goa, 2017), or as a process through which teachers learn to enhance their commitments to the teaching profession (Day, 1999). However, views regarding the professional development of teachers differ from one nation to another. In the context of China, respecting teachers at all levels of education and attaching great value to them is traditional (Yu, 2013).

Chinese teacher education and training (CTET) has a history of over 100 years, facing many political and economic challenges and changes (Yang \& Wu, 1999). These led China to prioritize teacher education development that included the upgrading of the social status of educators, and the improvement of their working and living conditions. The Chinese government has paid attention to teachers' development, following the fact that preparing high-quality students demands high-quality teachers (Joyce, 1980). This acknowledgement led to considering several measures toward the promotion of teachers' educational development. This is mainly reflected in the policy document entitled "suggestions for improving and developing teacher education" issued by the Ministry of Education in 1978 (Yang \& Wu, 1999, p. 158). Among many, three crucial laws and regulations related to teacher education and training were issued: Teachers Law, Education Law and Regulations on Continuing Education for primary and secondary teachers which were enacted in 1993, 1995 and 1999 respectively (Hu, 2005). These laws and regulations justify the interest of the Chinese government in preparing teachers who can contribute to ensuring education quality. Further, the government advocated for the importance of teacher education at a large scale conference on teacher education and training hosted by the State Education Commission in 1996 (Yang \& Wu, 1999). Given the relevance of improving teacher's education quality, the State Education Commission (1996) mentioned that teacher education should:

Implement the all-round national policies on education, adhere to the socialist principle of education, enhance all reforms in teacher education and improve its quality and effectiveness; promote the overall standards for teacher education, meet the demands for teachers both in quality and quantity; build up a teacher education system with Chinese socialist characters which embodies the ideology of life-long education, and gradually modernize teacher education. (as cited in Yang \& Wu, 1999, p. 160).

Historically, normal colleges and universities played an important role in the teacher education system in China. Among the teacher education institutions in China, the Normal School of Nanyang Gongxue is the first institution established in 1896 (Yu, 2013). However, in recent years not only normal colleges but also outstanding comprehensive universities began to play an active role in teacher education development. There is a growing tendency for other universities to attach great importance to teacher education. Moreover, Yang and $\mathrm{Wu}$ (1999) stated that the Chinese government has issued secondary schools with a set of professional standards for teachers to achieve through in-service training programs. They also mentioned that these standards are reflected in the curriculum for all in-service training programs including EFL teacher education programs. The in-service education of secondary EFL teachers is considered as a part of continuing professional development that would help bridge the gaps in the existing pre-service EFL teacher education in China ( $\mathrm{Hu}, 2005)$.

Teacher professional development is a core aspect of teacher professionalism and quality (Lee, 2010). As teacher professional development can be viewed as a tool to develop theoretical knowledge and practical 
experiences of teachers, this review paper reports on the state of secondary EFL teacher professional development in China. The review of relevant studies on secondary school EFL teacher professional development in China primarily aims to answer this basic research question: What is the state of secondary EFL teacher professional development in China?

\section{Literature search and analysis strategies}

For the purpose of searching for articles pertinent to this review paper, the two primary authors accessed different electronic databases. These databases included but not limited to Elsevier ScienceDirect, ProQuest, JSTOR, and SAGE. Moreover, articles which are not available in these databases were accessed through web searches. In the course of finding relevant articles, the two primary authors used key words and phrases including China, English, professional development, EFL, secondary school teachers, EFL teachers, and teacher professional development. After accessing the articles, attempts were made to identify the purpose of the articles by reading the abstracts. This led to deciding on the relevant studies that would answer the question of the review paper. The two primary authors also reviewed each selected article and noted all relevant arguments. Reading through the collected notes (reviews), the authors attempted to answer the paper key question in the form of the following three themes.

\subsection{English in China: Development and importance}

The phenomena of globalization and communication among different cultures have also influenced the internationalization of education in China. However, teaching English in China has a long history. According to Keqiang (1986), teaching English as a foreign language (TEFL) in China began in "the latter half of the $19^{\text {th }}$ century with the westernization movement started by some Chinese officials in the Qing Dynasty and with this came the influence of Western culture, trade and commerce" (p. 153). It is stated that China had given a due emphasis on the English language after the Ministry of Education had recognized it useful for learning science and technology from the Western countries in 1956 (e.g. Wenzhong \& Hu, 2001).

Regarding English language teachers' training programs, Keqiang (1986) stated that Tongwen Guan, the first English teaching institution, was founded in 1862 which later became the part of the Beijing Normal University in 1902 although the curriculum had abandoned foreign language learning during the Cultural Revolution. In this regard, Wenzhong and $\mathrm{Hu}$ (2001) mentioned that because of the lack of policy regarding language education in China, the foreign language teaching was underdeveloped in 1950s. There was a time when English was considered as useless, and therefore the English language department in seven normal universities was closed in 1953. This had implication on the English language teaching and learning in secondary schools (ibid, 2001). However, the "Four Modernization Program" and "Open-Door Policy" assisted Chinese people of all ages and occupations to recognize the importance of learning the English language (Keqiang, 1986). More specifically, Cheng (1988) emphasized how English language usage and teaching in China developed after the endorsement of the modernization of agriculture, industry, science and technology, and national defense. It is important to note that "English education system, the actual starting point of English teaching and learning is the junior high school, and the new starting point for the English education system is from the first or the third grade of primary schools" (Liu \& Dai, 2011, p. 106). Currently and specifically in big cities, regular English classes are offered even in some kindergartens (Lee, 2010). This is due to the common recognition that a foreign language should be learned as early as possible in order to set up a firm base (Keqiang, 1986) and to help young children learn English early so that they can succeed in achieving high marks, joining outstanding universities and ensuring bright futures in their career (Lee, 2010).

The people in China believe that learning English would contribute to economic and social development (Adamson, 2004). This encourages the government to take further significant measures to popularize English among the Chinese people. Concerning its popularity and usage, Lee (2010) reports that English has become more crucial and widespread all over China since the enlistment of the World Trade Organization in 2001, the 
hosting of the 2008 Beijing Olympics, and the Expo 2010 in Shanghai. The English language books prepared for policemen and taxi drivers became available at different bookshops (Jiang, 2003 as cited in Lee, 2010). There has still been increasing passion for learning English in China and the government has long recognized the growing importance of the English language education. The English language has been considered as an important tool for the development of a nation in different ways (Cortazzi \& Jin, 1996). With English proficiency, people would be able to receive good-quality higher education, find jobs, run business with people from other countries, study abroad, and acquire necessary information from foreign resources. More importantly, English has become a preferred foreign language at secondary schools after the foundation of the People's Republic of China (Wenzhong \& Hu, 2001).

Given the importance of the English language in the current world, a large number of Chinese EFL teachers have been attending regular English courses in order to be competent in teaching the language (Zheng, 2012). It is apparent that providing training for English teachers is a resource intensive activity (Hu \& Alsagoff, 2010). As part of a top-down effort, the Chinese government has invested much resource to improve EFL instruction in secondary schools $(\mathrm{Hu}, 2004)$. In order to enhance the quality of English language instructions at secondary schools, other efforts have also been made including the improvement of curriculum, syllabus, textbooks, and examination system (Hu, 2004). Regardless of such efforts to improve the EFL teaching and learning at secondary schools, students still focus on knowledge acquisition with the aim of getting high scores through rote learning, as teachers themselves rarely deliver interactive lessons (Yua \& Wangb, 2009).

On the other hand, a case study showed that secondary EFL teachers who promote student's "cognitive" and "affective development" tend to employ "innovative communicative approaches", while those who expect students to achieve immediate leaning outcomes, predominately use "behaviourist approach" (Zheng, 2013). This clearly indicates how students learning could be influenced by teachers' teaching strategies which could be improved through continuous professional development. With the aim of a successful adaptation to the new situation, the Chinese Ministry of Education (MOE) has attached more importance to the TEFL and improved the curriculum and syllabus of English language programs at the higher learning institutions to train secondary school EFL teachers (Meng \& Tajaroensuk, 2013).

\subsection{The value of EFL teacher professional development in China}

The requirements, standards and professionalism of teaching English as a foreign language have increased and this might be due to the widespread of English accompanied by individual's learning interests and enthusiasm. China put emphasis upon secondary EFL teacher professional development programs, believing that the English language has its own contribution to the modernization program which was initiated in the late 1970s (Hu, 2005). In-service teacher education would enhance the quality of teachers. Therefore, improving the professionalism of EFL teachers demands the presence of quality in-service professional development programs (Meng \& Tajaroensuk, 2013). This led to the enactment of the Teachers' Law that highlighted the participation in continuous professional development programs to be the right of and obligation for teachers of English ( $\mathrm{Hu}$, 2005). Further, different stakeholders of the Chinese education sectors underscored the importance of improving the quality of the English language instruction at all stages (Li \& Hudson, 2011).

Globalization dictates reforms on teaching and teacher professional development programs in China and these reforms can also be considered as part of the globalization process (Paine \& Fang, 2006). In this regard, the Ministry of Education of China issued the National English Language Teaching guidance in order to coordinate English language education at all school levels with the purpose of keeping abreast of global curriculum reforms (Zhang, 2012). It seemingly appears that the "overarching goal of secondary English instruction set by the current secondary curriculums is communicative competence in English" (Hu, 2005, p. 658). This urged the government to further their efforts to improve the syllabus for students majoring English in 2001 (Meng \& Tajaroensuk, 2013). They also added that the Chinese Ministry of Education issued requirements for the curriculum of English at the college level. This led to holding the belief that outdated pre-service trainings and 
A review of secondary school EFL teacher professional development in China

the inadequate in-service support for teachers of English were among the reasons that made teachers incompetent to use the new English language textbooks (Jin \& Cortazzi, 2003).

With the new curriculum reform, Chinese EFL teachers started to have some dilemmas between the traditions and innovations, and theory and practice. Among many, the new curriculum and pedagogy of the English language in China developed by the Ministry of Education in 2001 recommended the use of the student-centered teaching approach with an emphasis on communication (Yua \& Wangb, 2009). This necessitated the improvement of the pedagogical skills of the in-service English teachers. In other words, the curriculum reform demands EFL teachers to meet a high standard (Zheng, 2012). As improving the quality of teachers has been a challenging task in China (Guo, 2005), the Chinese government hosted a massive teacher training program wherein millions of English language teachers participated from 2001-2008 (Zhang, 2012). Furthermore, Zhang (2012) stated that this massive program is supposed to qualify a huge number of teachers of English for the successful implementation of the new 'National English Teaching Guidance and the National English Language Curriculum Standard' throughout the country. The new ELT syllabus in higher education institutions and the education reform of China recommend the use of the communicative method (in teaching) which promotes learner-centered learning (Ministry of Education, 2000). This implies that the Chinese EFL teachers in colleges and universities are expected to change their lessons from traditional design into oral communication activities.

China has also established a testing system for learners majoring in English language and literature. According to Cheng (2008), major English tests -which are locally designed- include the College English Test (CET), the National Matriculation English Test, the Test for English Majors (TEM), the Graduate School Entrance English Examination (GSEEE), the Public English Testing System (PETS), the Cambridge Business English Certificate (CBEC) and the Waiyu Shuiping Kaoshi (WSK)-an examination to select professionals who want to attend further study and training overseas. Among other English tests, the TEM is a significant test for English major students in colleges and universities (Cheng, 2008). It is a criterion-based test designed for undergraduate students who are studying English Language and Literature (Jin \& Fan, 2011). They also described that TEM helps to "examine whether these students meet the required levels of English language abilities as specified in the National College English Teaching Syllabus for English Majors” (Jin \& Fan, 2011, p. 549).

\subsection{EFL teacher professional development: Actual practices}

The reform of school curriculum created tensions between the traditions and the innovations, theory and practice for teachers (Zheng, 2012). Student's learning is improved by supporting teachers to create positive changes. Without any concern for teachers' knowledge and daily practices, reform is considered as imposition of something on teachers regardless of its perceived importance (Villegas-Reimers, 2003). In order to enable teachers to implement innovative methods and techniques, teacher education programs need to "empower teachers with the knowledge, skill, attitude, and autonomy necessary to devise for themselves a systematic, coherent, and relevant alternative ... method that is informed by principled pragmatism" (Kumaravadivelu, 1993 as cited in Zheng, 2012, p. 9). As a result, the Chinese government has been offering financial support to in-service training programs to sustain continuous professional development of teachers' practices (Hu, 2005). Yet, some research reported the insufficiency of professional support for teachers which results in poor teacher's quality (e.g., Dai, 2008; Guo, 2005).

The EFL teacher education in China has failed to keep pace with the development of the English curriculum (Zheng, 2012). Together with curriculum reform, new regulations, standards and systems of accountability have been appeared in China with the intention of raising the qualifications and quality of China's teachers since 1990s (Paine \& Fang, 2006). However, secondary school EFL teachers in china have not been receiving adequate professional support to develop their profession (Zheng, 2012). It is clear that "the demand for new kinds of teachers, and new professional development, is particularly challenging given the unevenness of China's 
Urgamal, L., Taye, M., Muthanna, A., \& Sang, G.

enormous teaching force" (Paine \& Fang, 2006, p. 288).

Teacher professional development programs are supposed to enable teachers to adapt with the changing world and contribute to the success of various educational reforms proposed by a state. However, the existing professional development program for EFL teachers showed less progress (Zheng, 2012). This is attributed to the problem that "the vast majority of the upgrading programs simply adopt or make a limited adaptation of the curriculum and teaching materials for pre-service teacher education programs" (Hu, 2005. p. 20). Further, the instructional and evaluation practices of the in-service programs are traditional and emphasize the transmission of a fixed knowledge base. In this regard, $\mathrm{Hu}$ (2005) argued that this approach of instruction failed to create connection between teacher's teaching experience acquired through practice and theory. Moreover, because of the lack of qualified English language trainers and English teaching knowledge and skills of participants, the in-service training programs did not achieve the required results (Dong \& Gui, 2002). As English language teacher educators are new to the EFL teaching and course plans in secondary schools contexts, they face problems in delivering training for secondary EFL teachers (Hu, 2005). This is in line with the claim that most professional development programs failed to achieve the expected goals regardless of the way they are designed (Ono \& Ferreira, 2010). The study conducted by Liu (2006) showed that among 126 participating teachers, $49.2 \%$ of the teachers seemed to be reluctant to participate in teachers' training programs, and the majority of the study participants $(74.8 \%)$ believed that using teacher-centered teaching approach may result in ineffective teacher training program.

\section{Conclusion, contributions, and implications}

This review paper provides a critical overview of the secondary EFL teacher professional development in China. Teacher professional development is the core aspect of teacher professionalism and quality. However, China still needs to further fulfill the professional support of EFL teachers at the secondary school level. In order to encourage teachers to participate in continuous professional development, it is important to provide them with incentives to successfully complete the training program. Policy makers and practitioners must play a great role in realizing professional development of teachers by proposing different supports based on the actual needs of teachers. Moreover, it is essential to engage EFL teachers in participating in the designing of professional development program. It is significant that teachers are given autonomy in making decisions regarding the classroom instruction and adjusting the curriculum based on classroom conditions. Further, reviewing the actual teaching practices of EFL teachers in the classrooms is needed in China as there had been little information regarding English language instruction and teachers' professional development practices in secondary and primary school contexts (Wenfeng \& Gao, 2008). By reporting the state of secondary EFL teacher professional development, the review paper distinguishes between the value given to secondary EFL teacher professional development and the actual in-service training experiences. This distinction is of benefit to EFL curriculum experts, principals, trainers, and teacher educators who should collaboratively work for the improvement of EFL teacher professional development practices. This would in effect help enhance students' learning in classrooms. Furthermore, providing financial incentives to secondary EFL teachers would motivate them to further develop their teaching professional skills.

\section{References}

Adamson, B. (2004). China's English: A history of English in Chinese education. Hong Kong: Hong Kong University Press.

Cheng, H. (1988). Teaching English as a foreign language in China. TESL Canada Journal, 5(2), 88-94. https://doi.org/10.18806/tesl.v5i2.534

Cheng, L. (2008). The key success: English language testing in China. Language Testing, 25(1), 15-37. https://doi.org/10.1177/0265532207083743

Cortazzi, M., \& Jin, L. (1996). English teaching and learning in China. Language Teaching, 29(2), 61-80. https://doi.org/10.1017/S0261444800008351 
A review of secondary school EFL teacher professional development in China

Dai, W. (2008). The report of foreign languages education development in tertiary education (1978-2008). Shanghai: Shanghai Foreign Languages Education Press.

Day, C. (1999). Developing teachers: The challenges of lifelong learning. London, England: Falmer.

Day, C., \& Sachs, J. (2004). Professionalism, performativity, and empowerment: Discourses in the politics, policies and purposes of continuing professional development. In C. Day, \& J. Sachs (Eds.), International handbook on the continuing professional development of teachers (pp. 3-32). Maidenhead: Open University Press.

Dong, Y. P., \& Gui, S. C. (2002). Current foreign languages education in China. Journal of Modern Foreign Languages, 4, 2-16.

Goldschmidt, P., \& Phelps, G. (2010). Does teacher professional development affect content and pedagogical knowledge: How much and for how long? Economics of Education Review, 29, 432-439. https://doi.org/10.1016/j.econedurev.2009.10.002

Guo, S. (2005). Exploring current issues in teacher education in China. The Alberta Journal of Educational Research, 51(1), 69-84.

Hu, G. (2004). Pedagogical practices in Chinese EFL classrooms. Asian Englishes, 7(1), 42-59. https://doi.org/10.1080/13488678.2004.10801130

Hu, G. (2005). English language education in China: Policies, progress, and problems. Language Policy, 4(1), 5-24. https://doi.org/10.1007/s10993-004-6561-7

Hu, G., \& Alsagoff, L. (2010). A public policy perspective on English medium instruction in China. Journal of Multilingual and Multicultural Development, 31(4), 365-382. https://doi.org/10.1080/01434632.2010.489950

$\mathrm{Hu}, \mathrm{W}$. (2001). A matter of balance-reflections on China's language policy in Education. Asian Englsihes, 4(1), 66-79. https://doi.org/10.1080/13488678.2001.10801064

Jiang, Y. (2003). English as a Chinese language. English Today, 19(2), 3-8.

Jin, L., \& Cortazzi, M. (2003). English language teaching in China: A bridge to the future. In W.-K. Ho \& R. Y. L. Wong (Eds.), English language teaching in East Asia today (pp. 131-145). Singapore: Times Academic Press.

Jin, Y., \& Fan, J. (2011). Test for English majors (TEM) in China. Language Testing, 28(4), 589-596. https://doi.org/10.1177/0265532211414852

Joyce, B. (1980). The ecology of professional development. In E. Hoyle \& J. Megarry (Eds.), World yearbook of education: Professional development of teachers (pp. 19-41). London: Kogan Page.

Keqiang, W. (1986). Teaching English as a foreign language in China. TESL Canada Journal, 3, 153-160. https://doi.org/10.18806/tesl.v3i0.1001

Kumaravadivelu, B. (1993). Maximizing learning potential in the communicative classroom. English Language Teaching Journal, 47(1), 12-21.

Lee, J. F. (2010). Perceptions of ELT among English language teachers in China. Education Journal, 37 , $137-154$.

Li, B., \& Hudson, P. (2011). Understanding Chinese TEFL academics' capacity for research. Journal of Further and Higher Education, 35(3), 391-407. https://doi.org/10.1080/0309877X.2011.569014

Liu, J., \& Dai, Z. (2011). The impact of the advent of English in primary schools on the development college English in China. Higher Education Studies, 1(1), 105-108. https://doi.org/10.5539/hes.v1n1p105

Liu, X. (2006). Exploration of issues and models of new curriculum training for rural junior high school English teachers. Foreign Language Teaching and Research in Basic Education, 70(12), 51-53.

Meng, J., \& Tajaroensuk, S. (2013). An investigation of tertiary EFL teachers' problems in their in-service professional development. Journal of Language Teaching and Research, 4(6), 1356-1364. https://doi.org/10.4304/jltr.4.6.1356-1364

Ministry of Education. (2000). Gaodeng Xuexiao Yingyu Zhuanye Yingyu jiaoxue Dagang [The National Syllabus for English Majors at Tertiary Level]. Shanghai: Shanghai Foreign Languages Education Press.

Ono, Y., \& Ferreira, J. (2010). A case study of continuing teacher professional development through lesson study 
Urgamal, L., Taye, M., Muthanna, A., \& Sang, G.

in South Africa. South African Journal of Education, 30, 59-74.

Paine, L. W., \& Fang, Y. (2006). Reform as hybrid model of teaching and teacher development in China.

International Journal of Educational Research, 45(4-5), 279-289.

https://doi.org/10.1016/j.ijer.2007.02.006

State Education Commission. (1996). Suggestions concerning the reform and development of teacher education. Beijing: State Education Commission.

Tao, J., \& Gao, X. (2017). Teacher agency and identity commitment in curricular reform. Teaching and Teacher Education, 63, 346-355. https://doi.org/10.1016/j.tate.2017.01.010

Villegas-Reimers, E. (2003). Teacher professional development: an international review of the literature. Paris: UNESCO International Institute for Educational Planning.

Wenfeng, W., \& Gao, X. (2008). English language education in China: A review of selected research. Journal of Multilingual and Multicultural Development, 29(5), 380-399. https://doi.org/10.1080/01434630802147908

Wenzhong, H. (2001). A matter of balance-reflections on China's language policy in education. Asian Englishes, 4(1), 66-79.

Yang, D. P., \& Wu, J. Q. (1999). Some issues in the reform and development of teacher education and training in China. Teacher Development, 3(2), 157-172. https://doi.org/10.1080/13664539900200078

Yu, T. (2013). Teacher Education in China: Current situation and related issues [PowerPoint slides]. Retrieved from https://docplayer.net/1863948-Teacher-education-in-china-current-situation-related-issues.html

Yua, Y., \& Wangb, B. (2009). A study of language learning strategy use in the context of EFL curriculum and pedagogy reform in China. Asia Pacific Journal of Education, 29(4), 457-468.

https://doi.org/10.1080/02188790903309041

Zhang, W. (2012). A brief introduction to foreign languages education policy in China. ERIC online submission. Retrieved from http://eric.ed.gov/?id=ED530281

Zheng, H. (2012). Dilemmas in teacher development in the Chinese EFL context. Journal of Cambridge Studies, $7(2), 2-16$.

Zheng, H. (2013). The dynamic interactive relationship between Chinese secondary school EFL teachers' beliefs and practice. The Language Learning Journal, 41(2), 192-204.

https://doi.org/10.1080/09571736.2013.790133 